\title{
Institutional Quality and Foreign Direct Investment (FDI) In Nigeria: A Prognosis
}

\author{
Ntim Gyakari Esew, Emilia Yaroson \\ ${ }^{I}$ Department of Political Science, Kaduna State University \\ ${ }^{2}$ Department of Business Administration, Kaduna State University
}

\begin{abstract}
Foreign direct investment has been recognized by many research experts as one of the most secure elements of capital inflows capable of triggering economic expansion in developing economies but empirical literature provides mixed results as to what factors are capable of attracting substantial foreign investments into Nigeria. The aim of this paper therefore is to investigate the impact institutional quality has in attracting FDI flows into Nigeria from 1980 -2011. The Vector Error Correcting Model (VECM) is employed to examine the relationship between these macroeconomic variables. The result from the empirical analysis shows that political stability and corruption are major determinants of FDI inflows to Nigeria. Other significant determinants include human capital and trade openness. The study therefore recommends the strengthening of political and economic institutions in Nigeria to attract any meaningful foreign investments.
\end{abstract}

Keywords: Foreign Direct Investment, Nigeria, Political stability, VECM

\section{Introduction}

Foreign Direct Investment (FDI) which is a core element in economic globalization has received increasing interest as to what factors propel this macroeconomic variable in developing countries. This is because FDI is measured as one of the most secure elements of investment flows to developing countries (Bénassy-Quéré et al 2007) and a major stimulant of economic performance through saving accumulation, transfer of modern technologies, foreign exchange enhancing competition, developing of local manpower and access to foreign markets (Akinlo, 2004; Rodrik, 1998; Anyawu 2007; Dunning 2001; Borensztein et al, 1998; Dupasquier and Osakwe, 2003; Anyanwu, 2003).These benefits are not unfamiliar to policymakers in developing countries as most of these economies are liberalizing their policies and offering various incentive packages to attract foreign investors. However, most of these countries have still failed to attract tangible foreign investors capable of triggering economic expansion.

The question therefore arises as to what actually determines inflow of Foreign Direct Investment to developing economies? There are numerous theoretical and econometric literatures on the determinants of FDI in developing economies but the results are still inconclusive as the evidence provided in empirics are rather untidy and sometimes perplexing. These shortfalls may emanate from the issue of getting reliable proxies for the qualitative trend or the methodology employed. For instance, Asiedu (2002); Anyanwu,(2010); Adeoye (2009) ,employ telephones to measure infrastructure development. This proxy fails to capture the reliability and efficiency of the infrastructure of the host country. As there may be telephones lines made available to almost $70 \%$ of the population of a country but its economy may be handicapped by poor transportation systems, energy shortages and a poorly developed financial sector which can increase the transaction cost and risks to foreign investors and thus can affect FDI inflow negatively. Furthermore, the traditional determinants of FDI which include natural resources Dupasquier \& Osakwe (2006); Asiedu, 2002;, market size Shatz \&Venables,(2009) trade openness (Torriss et al 2008) and human capital; among others have been largely distorted by the effect of economic globalization and financial crises (Nunnenkamp, 2001). These have resulted in the paradigm shift to institutional infrastructure's ability to attract FDI inflows as pointed out by Yarram \& Al Farooque, (2010). The underlying principles behind the importance of institutional quality in attracting FDI's are attributed to what constitutes these qualities. For instance, good institutional qualities which are often characterized by political stability, absence of violence; control of corruption and the rule of law in the host country are more likely to convince and attract foreign investors. As indicated by Wei (2000) who explains that where institutional quality is lacking as reflected in corruption of civil servants, bureaucracy and high levels of extortions may spawn mistrust which may be unhealthy for doing business both for domestic and foreign investors. Therefore, poor institutional quality may lead to unnecessarily high costs in doing business in a highly corrupt economy. More so, property rights are not well defined, which may lead to high risks of expropriation and hence may discourage investors to patent their products to local enterprises. It is therefore crucial to take into cognizance the peculiar rudiments in analyzing the political economy underpinning FDIs. The empirical evidence on the impact of institutional quality in explaining behaviour of FDI flows have been relatively limited in Nigeria, despite the 
huge amount of literature that exist on the drivers of FDI. This rarity of empirical studies could be ascribed to the lack of information and data on quantifying the quality of institutions in the past.

This study therefore aim's to investigate the relationship between institutional quality, foreign direct investment (FDI), and its determinants in Nigeria. If my assertions stand correctly, then this paper hopes fill in the gap in existing literature by providing empirical evidence on the importance of institutional quality in determining FDI inflows to Nigeria. This is an introduction to the study. The next section reviews relevant literature and the proposed hypothesis; while section three presents the methodology employed in the study. The results and discussions are presented in the next section and then conclusions are drawn based on the findings in the final section.

\subsection{Theoretical Background}

\section{Review Of Relevant Literature}

There are several theories that exist in an attempt to rationalize the decisions for MNC to invest in a foreign market they range from Vernon's (1966) economic theories, to the internationalization theories posited by Rugman (1981). However, Dunning $(1988,1993)$ is notable for his exposition on the criteria that determines investment in foreign markets as well as the motives for such investments. Explaining that a firm's decision to invest abroad is based on one or all of these major motives; resources seeking; here firms seek to invest in countries rich in resources not readily available in their home country which include natural resources or low cost of labour ; market seeking: also referred to as horizontal FDI. The main aim of firms here is to serve the host market through replicating their production facilities locally, while Market size in terms of the country's population, the growth of the economy and high tariffs or transportation cost plays important roles in this type of FDI; Efficiency-seeking: if MNC can benefit from the common governance of geographically dispersed activities in the presence of economies of scale and scope, they may seek to invest in such countries. This paper therefore adopts and augments the underlying theory as laid down by Dunning (1993).

\subsection{Empirical literature}

Considerable amount of empirical literature also exist in an attempt to support Dunning's assertion, but the major problem with these findings is that the results produced are inconclusive. On one hand, Nonnemberg and Mendonca (2004); Obadan (1982); Masayuki and Ivohasina (2005); Artige and Nicolini (2005); Wafure\& Nurudeen (2010) find market size a significant determinant of FDI in host countries by employing GDP as a proxy while, Prabirjit (2007) presents evidence of a negative, relationship between market size and foreign direct investment. Also, Asiedu (2002) \& Wei (2000) have reported the absence of significant relationship between host market size and the inflow of FDI. The difference in outcomes may possibly arise from the differences in the economies under study and possibly the time frame which were adopted. Another likely explanation may be that the size of national income employed may be too small to have any significant impact on FDI. That notwithstanding, market size still serves as a very robust determinant of FDI, as Jordan (2004) explains that multinational corporations will seek to invest in countries with expanding markets and greater purchasing power where they can receive higher profits from their investment. Similarly, Chakrabarti (2001) posits that the market size hypothesis is based on the notion that a large market is required for a firm to efficiently use available resources and reap the benefits accrued to economies of scale.

There are also mixed evidence presented in an attempt to ascertain if the level of human capital within an economy may be responsible for attracting foreign investors to host countries (Nonnemberg and Mendonca 2004; Noorbakhsh et al. 2001). The variables employed in these studies include secondary school enrollment, accumulated years of secondary schooling, and combined tertiary and secondary education in working population. Their studies find all three variables significant and conclude that human capital over time have become of greater importance in determining FDI.

Institutional quality has also been attributed as one of the leading factors that attract foreign direct investment in developing economies in recent years (Bisson, 2011; Anghnel, 2005); Wernick, 2008, 2009; Daude and Stein, 2007). While some researchers have paid careful attention to role good economic institutions plays in the host countries, (Bénassy-Quéré et al. (2007), others have attempted to appraise the impact of political institutions and stability on FDI inflow (Jensen, 2008); Busse and Hefeker, 2007; Biglaiser, 2009); Roberts, 2006). Notably, is the empirical work of Zheng (2006) where there is strong statistical evidence to support an inverted U-shape relationship between political institutions and FDI. Here, the presence of weak political institutions at the beginning of the period under study supports FDI but as political stability sets in, FDI inflows continuously drops until there is no significant impact. In this specific case it could be argued that strengthening of political institutions simply diminished FDIs flows. The possible explanation maybe the establishment of rules by the new government may not support FDI thereby frustrating foreign direct investors.

With particular reference to Nigeria, there is still limited empirical evidence on the importance of institutional quality in determining FDI in the country. As most of the available literature either employs pooled 
regression strategy in their analysis which fails to capture the peculiarities of the individual countries' institutional quality (Asiedu, 2002; Anyawu, 2006; Adeoye, 2009) or the time frame involved is inappropriate or they fail totally to control for institutional quality. For instance, Uwubanmwen \& Ajao (2012) attempt to examine the determinants of foreign direct investment in Nigeria for the period (1970-2009). Their results reveal that exchange rate, interest rate, inflation and trade openness play an important role in attracting FDI inflows into Nigeria. This study however fails to control for institutional quality such as political stability, regulatory institution and corruption. In the same way, Nwankwo,(2006) tries to identify the main determinants of FDI inflows in Nigeria for the period between (1962-2003). The findings reveal that a strong market and macroeconomic stability promote FDI while political instability deters it. Although, the paper controlled for political instability, frequency of coup d'états and transition to democracy were employed as a yardstick in measuring the level of political instability. As such the study fails to take into consideration the present nature of political crises encountered in the economy. Also, the study carried out by Oke et al (2012), find political stability and energy consumption as significant predictors of foreign direct inflows. While exchange rate market size infrastructure and human capital are irrelevant in determining foreign investment. In light of the foregoing, the next section presents the variables adopted in the study and the appropriate empirical necessary for carrying out the analysis.

\subsection{Scope of the study}

\section{Methodology And Empirical Strategy}

The aim of this paper is to examine the impact institutional quality has in determining foreign investment in Nigeria. The study covers the sample period between $1980-2011$. This is because the sample period captures the actual development of foreign direct investment into Nigeria and periods of coup d'états, democracy and the upsurge of corruption.

\subsection{Variables Specification}

Based on theoretical assertions, the study adopted the following variables

Dependent variable; the dependent variable for the purpose of this study is the sum FDI inflows as a share of GDP. This refers to investment of capital nature made to obtain long term controlling shares in a firm operating in another country other than the investors' country. This variable is irrespective of portfolio investment.

Market size to measure the size of the market, the study employs Gross Domestic product (GDP)(Asiedu,2002;Nwankwo,2006). The idea here is that bigger markets provide more prospects for local sales because local sale yields more profit than exports especially where there is advantage of economies scale (Dunning, 1993). To this effect, we propose a positive relationship between FDI and GDP. The variable is sourced from CBN statistical bulletin

Institutional Quality in measuring institutional quality of the host country, this study adopts the political stability/absence of Violence index developed by Kaufmann et al (2006). This proxy is employed based on the notion that a political stable economy would lead to economic growth. A vibrant and economically developed economy would attract foreign investors. Hence, a positive relationship between political stability and foreign investment is expected. More so, the study uses the corruption perception index (CPI) (Transparency international, 2012), in measuring the level of institutional soundness within the economy. Although the theory underlying the link between corruption and FDI is inconclusive, a negative relationship is expected.

Human capital development (HC) the ratio of secondary school enrollment is used as a proxy in measuring the level of education of the host country. This is based on the principle that the higher the level of education of the host country, the higher its propensity to attract foreign investors and technological spillover is encouraged. Hence, we expect a direct correlation between the two macroeconomic variables.

Macroeconomic stability: an economic stable economy attracts investors as it reduces the risk and the cost of doing business within an economy. Inflation rate measure by consumer price index is used as a proxy for macroeconomic stability. Therefore, high inflation rates, signals macro economic instability which implies the government's inability to balance the budget and the Central bank's inability to control the supply of money (Fisher, 1993). Hence an inverse relationship is expected between inflation and FDI inflows.

Infrastructure; the availability of good infrastructure such as roads and energy supply will reduce the cost of doing business for investors and the ability of these investors to maximize the rate of return of their investment. Foreign investors will have a preference for host countries with infrastructures which will facilitate communication, transportation and distribution of goods and services (Asiedu, 2002). This study adopts the supply of energy as a proxy for infrastructural development.

Financial development; an efficient financial system is necessary in attracting capital investment, as a secure capital and money market would provide the necessary financial assistance and a sure way of exit. In this study, stock market capitalization and domestic credit to the private sector are the parameters used in measuring the depth of the financial system .this data is retrieved from the Central bank of Nigeria Statistical Bulletin. 
Trade openness; this is the share of trade (imports and exports). An economy that has restrictive trade policies impedes FDI, while economies that have liberal trade policies encourage FDI. The World Bank development index permits the collection of this data

\subsection{Models Specification}

The aim of this paper is to model the relationships between institutional quality, foreign direct investment (FDI), and its determinants in Nigeria for the years 1980 through 2011. As part of the methodological design, the basic estimating equations in log linear form are specified as follows:

LNFDI=f $\{$ INQLTY, HC, MKTSIZE, FD, MSTBLTY, INFRST, TRADE $\}$ $\operatorname{eqn}(1)$ Therefore,

Lnfdi $=\alpha_{0}+\alpha_{1}$ inqlty $_{t}+\alpha_{2} \operatorname{lnh}_{t}+\alpha_{3} \operatorname{lngdp_{t}}+\alpha_{4} \operatorname{lnfd} d_{t}-\alpha_{5} \operatorname{lniflation}_{t}+\alpha_{6} \operatorname{lninf~rast~}_{t}+\alpha_{7} \operatorname{lntrade}_{t}+$ $\varepsilon_{\mathrm{t}}($ eqn 2)

Where: $\alpha_{0}-\alpha_{7}$ are the parameter's to be estimated and $\varepsilon_{\mathrm{t}}$ is the stochastic error term assumed to be independently and identically distributed.

\subsection{Empirical strategy}

In an attempt to perform the empirical design, the nature of the data distributed is examined by employing the descriptive statistics which includes the mean, standard deviation skewness and kurtosis. While the normality test is established using the Jacque Bera test. Also, the stationarity properties of the variables employed in this study is examined using the Augmented Dickey Fuller test (ADF)(Dickey \&Fuller,1981) and confirmed using the Philip Peron test (PP).

The general form of the ADF \& PP test is estimated here

$$
\begin{aligned}
\mathrm{ADF}: & \rightarrow \Delta \mathrm{Y}_{\mathrm{t}}=\alpha_{0}+\alpha_{1} \gamma_{\mathrm{t}-1}+\sum_{\mathrm{t}=1}^{\mathrm{n}} \alpha \gamma_{\mathrm{i}}+\delta_{\mathrm{t}}+\mathrm{e}_{\mathrm{t}} \ldots \ldots \ldots \ldots \ldots \ldots \ldots \ldots \text { eqn } 3 \\
\mathrm{PP} & \rightarrow \Delta \mathrm{Y}_{\mathrm{t}}=\alpha_{0}+\alpha_{1} \gamma_{\mathrm{t}-1}+\mathrm{e}_{\mathrm{t}} \ldots \ldots \ldots \ldots \ldots \ldots \ldots \ldots \ldots \ldots \ldots \ldots
\end{aligned}
$$

Where $\mathrm{Y}$ is a time series, $\mathrm{t}$ is a liner time series trend, $\Delta$ is the first difference operator, $\alpha_{0}$ is the constant, $\mathrm{n}$ is the optimum number of lags in the dependent variable ande $e_{t}$ is the random error term.

The Johansen-Juselius Cointegration test is employed to model the long term relationship for the variables employed in this study (Johansen-Juselius,1992, 1999). This is method is adopted in order to solve for the problem of spurious regression that may occur.

Equation 2 is rewritten to know the disequilibrium error as

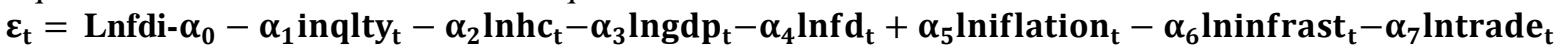
(5)

The order of integration of the estimated residual $\boldsymbol{\varepsilon}_{\mathbf{t}}$ is tested. If Cointegration exists, then equation (5) forms a stationary time series and has a zero mean. The $\boldsymbol{\varepsilon}_{\mathbf{t}}$ should be stationary, I (0) with $\mathrm{E}\left(\boldsymbol{\varepsilon}_{\mathbf{t}}\right)=\mathbf{0}$

The long run equilibrium may be rarely observed but there is a tendency to move towards equilibrium. As a result the Error Correction Model is used to represent the static and the dynamic links between FDI and other variables. Equation 6 represents the Error correction model for the study.

$\Delta \operatorname{lnfdi}_{\mathrm{t}}=\operatorname{lagged}\{\Delta$ INQLTY, $\Delta$ LNHC, $\Delta$ LNMKTSIZE, $\Delta$ LNFD, $\Delta$ LNMSTBLTY, $\Delta$ LNINFRST,$\Delta$ LNTRADE $\}-$

$\lambda \varepsilon_{\mathrm{t}-1}+\mu_{\mathrm{t}}(\mathbf{6})$

Where $\varepsilon_{t-1}$ denoted the residual term at $\mathrm{t}-1$.

The Vector Error Correction Model (VECM) is employed to test for the existence of a long term relationship in the equation only. If a cointegrating relationship is established from the Johansen-Juselius test, a Vector Error Correcting Model (VECM) is used to model the long run causality and the short run dynamics. The intention of the VECM is to indicate the speed of adjustments from the short run equilibrium to the long run equilibrium state. The greater the coefficients of the parameter the higher the speed of adjustment of the model from short run to long run. The VECM is estimated below

$$
\begin{aligned}
& \Delta \text { LNFDI }_{\mathrm{t}}=\alpha_{0}+\alpha_{1} \sum_{\mathrm{t}=1}^{\mathrm{n}} \Delta \operatorname{lnFDI} \mathrm{I}_{\mathrm{t}-1}+\alpha_{2} \sum_{\mathrm{t}=1}^{\mathrm{n}} \Delta \text { inqlty }_{\mathrm{t}-1}+ \\
& \alpha_{3} \sum_{\mathrm{t}=1}^{\mathrm{n}} \Delta \operatorname{lnh}_{\mathrm{t}-1}+\alpha_{4} \sum_{\mathrm{t}=1}^{\mathrm{n}} \Delta \operatorname{lngdp}_{\mathrm{t}-1}+\alpha_{5} \sum_{\mathrm{t}=1}^{\mathrm{n}} \Delta \operatorname{lnfd}_{\mathrm{t}-1}-\alpha_{6} \sum_{\mathrm{t}=1}^{\mathrm{n}} \Delta \text { lniflation }_{\mathrm{t}-1}+ \\
& \alpha_{7} \sum_{\mathrm{t}=1}^{\mathrm{n}} \Delta \text { lninfrast }_{\mathrm{t}-1}+\alpha_{8} \sum_{\mathrm{t}=1}^{\mathrm{n}} \Delta \text { lntrade }_{\mathrm{t}-1}+\beta_{1} \operatorname{ECM}_{(-1)}+\varepsilon_{\mathrm{t}}
\end{aligned}
$$

Where $\boldsymbol{\varepsilon}_{\mathbf{t}}$ is the error term, ECM (-1) is the error correction term, $\boldsymbol{\beta}_{\mathbf{1}}$ captures the run impact. The short run effects are captured through individual coefficients of the differenced terms $(\alpha)$ while the coefficients of the ECM variable contains information about the effect past values have on the present values the size and the statistical significance of the coefficients of the ECM measures the tendency of each variable to return to the 
equilibrium. If a coefficient is significant, it implies that past equilibrium errors plays a role in determining the current results.

Similarly the granger causality test is employed to determine if one variable (A) granger causes another variable (B). This test was developed by Granger (1988) and variable A is said to granger cause variable B if A aids in the predicting the behaviour of B or if the coefficients on the lagged of A's are statistically significant. The main idea of causality is simple, if A causes B, then changes in A should precede changes in B (Pindyck and Rubin field, 1998). Since the time series variables are found stationary the granger causality test is performed as follows:

\subsection{Descriptive Statistics}

\section{Empirical Result}

Table 1 Descriptive Statistics

\begin{tabular}{|c|c|c|c|c|c|c|c|c|c|c|}
\hline Variables & LNFDI & $\overline{\text { POLSTB }}$ & CPI & LNINFL & LNTRADE & $\overline{\text { LNGDP }}$ & $\overline{\text { LNHC }}$ & $\overline{\text { LNDCP }}$ & $\begin{array}{l}\text { LNSTMLA } \\
\mathrm{K}\end{array}$ & LNINFT \\
\hline Mean & 0.9894603 & -1.61482 & 0.56719 & 2.674246 & 4.131893 & 6.55172 & 3.288735 & 2.676951 & 2.178516 & 23.42837 \\
\hline Max. & 2.113787 & -0.69587 & 0.9932578 & 5.187012 & 4.578016 & 6.923197 & 3.652996 & 3.952032 & 3.952032 & 24.02036 \\
\hline Min. & -0.398669 & -2.04749 & 0 & -0.45783 & 3.32517 & 6.300528 & 2.189871 & 1.316329 & 1.316329 & 22.69303 \\
\hline Std. Dev. & 0.6274366 & 0.4171851 & 0.3170059 & 1.916146 & 0.3387447 & 0.158529 & 0.36440458 & 0.668017 & 0.668019 & 0.367602 \\
\hline Skewness & -0.485177 & 1.230036 & -0.469667 & -0.28363 & -1.117317 & 0.7364898 & 0.9517651 & 0.6519062 & 0.6159062 & -0.25667 \\
\hline Kurtosis & 3.570153 & 3.53465 & 2.19993 & 1.524709 & 3.190753 & 2.831212 & 4.170296 & 3.570153 & 2.718227 & 2.195344 \\
\hline Observation & 31 & 16 & 16 & 32 & 32 & 32 & 32 & 32 & 32 & 32 \\
\hline
\end{tabular}

The variables employed in this study are normally distributed as presented in table1 above. The standard deviations of the variables are also low in contrast to the mean revealing a small coefficient of variation. Also, the range of variation between the maximum and the minimum is fair while the level of skewness of each variable is mildly skewed. Near normality is also confirmed by the kurtosis values of around 3 in most of the variables.

\subsection{Unit root test}

Table 4.2 Augmented Dickey fuller Test (ADF) and Phillip Peron (PP)Test

\begin{tabular}{|c|c|c|c|c|}
\hline VARIABLES & \multicolumn{2}{|c|}{ LEVEL } & \multicolumn{2}{|c|}{ FIRST DIFFERENCE } \\
\hline LNDCP & $\begin{array}{l}\text { ADF } \\
-1.618 \\
(0.4740)\end{array}$ & $\begin{array}{l}\text { PP } \\
-1.767 \\
(0.3972)\end{array}$ & $\begin{array}{l}\text { ADF } \\
-5.138 * * * \\
(0.0000)\end{array}$ & $\begin{array}{l}\text { PP } \\
-5.134 * * * \\
(0.0000)\end{array}$ \\
\hline LNFDIINFLOWS & $\begin{array}{l}-3.134 * * \\
(0.0242)\end{array}$ & $\begin{array}{l}-2.994 * * \\
(0.0355)\end{array}$ & $\begin{array}{l}-10.746 * * * \\
(0.0000)\end{array}$ & $\begin{array}{l}-11.783 * * * \\
(0.0000)\end{array}$ \\
\hline LNGDPPC & $\begin{array}{l}0.679 \\
(0.9894)\end{array}$ & $\begin{array}{l}-0.008 \\
(0.9579)\end{array}$ & $\begin{array}{l}-5.168 * * * \\
(0.000)\end{array}$ & $\begin{array}{l}-5.306 * * * \\
(0.0000)\end{array}$ \\
\hline LNINFRAS & $\begin{array}{l}-1.266 \\
(0.6444)\end{array}$ & $\begin{array}{l}-1.259 \\
(0.6478)\end{array}$ & $\begin{array}{l}-6.580 * * * \\
(\mathbf{0 . 0 0 0 )}\end{array}$ & $\begin{array}{l}-6.608 * * * \\
(0.0000)\end{array}$ \\
\hline LNHC & $\begin{array}{l}-2.301 \\
(0.1718)\end{array}$ & $\begin{array}{l}-2.293 \\
(0.1741)\end{array}$ & $\begin{array}{l}-3.469 * * * \\
(0.0088)\end{array}$ & $\begin{array}{l}-3.399 * * \\
(0.0110)\end{array}$ \\
\hline LNTRADE & $\begin{array}{l}-1.256 \\
(0.6031)\end{array}$ & $\begin{array}{l}-1.439 \\
(0.5634)\end{array}$ & $\begin{array}{l}-5.323 * * * \\
(0.0000)\end{array}$ & $\begin{array}{l}-5.332 * * * \\
(0.0000)\end{array}$ \\
\hline LNINFLATION & $\begin{array}{l}-1.366 \\
(0.5985)\end{array}$ & $\begin{array}{l}-1.118 \\
(0.7076)\end{array}$ & $\begin{array}{l}-2.661 * \\
(0.0811)\end{array}$ & $\begin{array}{l}-2.627 * * * \\
(0.00875)\end{array}$ \\
\hline LNCPI & $\begin{array}{l}-1.224 \\
(0.6632)\end{array}$ & $\begin{array}{l}-1.295 \\
(0.6316)\end{array}$ & $\begin{array}{l}-4.336 * * * \\
(0.0004)\end{array}$ & $\begin{array}{l}-4.296 * * * \\
(0.0005)\end{array}$ \\
\hline LNSTKMKT & $\begin{array}{l}-1.637 \\
(0.4640)\end{array}$ & $\begin{array}{l}-1.402 \\
(0.5814)\end{array}$ & $\begin{array}{l}-7.306 * * * * \\
(\mathbf{0 . 0 0 0 0 )}\end{array}$ & $\begin{array}{l}\mathbf{- 8 . 0 8 1} * * * \\
(0.0000)\end{array}$ \\
\hline POLSTAB & $\begin{array}{l}-1.538 \\
(0.5149)\end{array}$ & $\begin{array}{l}-1.277 \\
(0.6338)\end{array}$ & $\begin{array}{l}-5.302 \\
(0.0000)\end{array}$ & $\begin{array}{l}-5.859 * * * \\
(0.0000)\end{array}$ \\
\hline
\end{tabular}

$*, * *, * * *$ denotes stationarity at $1 \%, 5 \%$ and $10 \%$ significance level respectively

Table 4.2 above presents the results of the unit root test and it reveals that all the variables are found to be non stationary in their levels(except LNFDI) for both the ADF and PP test. At the first level difference, the calculated statistics clearly rejects the null hypothesis of unit root at $1 \%$ and $5 \%$ significance level. The first difference for the ADF and PP test confirms that the variables are stationary and have the same order of integration I (1). The Johansen-Juselius Cointegration approach is applied to examine the long run relationship among variables

\subsection{Co-integration Results}


Table 4.3 Johansen Co-integration Test

\begin{tabular}{llllll}
\hline RANK & PARMS & LL & EIGENVALUE & TRACE STATS. & 5\%CRITICAL \\
& & & & & VALUE \\
\hline 0 & $\mathbf{4 2}$ & $\mathbf{4 . 7 4 7 3 8 8}$ & & $\mathbf{1 0 3 . 6 8 9 8}$ & $\mathbf{9 4 . 1 5}$ \\
1 & $\mathbf{5 3}$ & $\mathbf{2 2 . 0 4 9 2 3 4}$ & $\mathbf{0 . 7 0 9 4 1}$ & $\mathbf{6 9 . 0 8 6 1}$ & $\mathbf{6 8 . 5 2}$ \\
2 & $\mathbf{6 2}$ & $\mathbf{3 4 . 2 7 1 4 6 1}$ & $\mathbf{0 . 5 8 2 3 1}$ & $\mathbf{4 4 . 6 4 1 6}$ & $\mathbf{4 7 . 2 1}$ \\
3 & $\mathbf{6 9}$ & $\mathbf{4 3 . 6 4 5 9 3 1}$ & $\mathbf{0 . 4 8 8 0 9}$ & $\mathbf{2 5 . 8 9 2 7}$ & $\mathbf{2 9 . 6 8}$ \\
4 & $\mathbf{7 4}$ & $\mathbf{5 1 . 7 5 7 9 5 2}$ & $\mathbf{0 . 4 3 9 7 8}$ & $\mathbf{9 . 6 6 8 6}$ & $\mathbf{1 5 . 4 1}$ \\
5 & 77 & $\mathbf{5 6 . 3 6 0 8 4}$ & $\mathbf{0 . 2 8 0 2 0}$ & $\mathbf{0 . 4 6 2 8}$ & $\mathbf{3 . 7 6}$ \\
6 & $\mathbf{7 8}$ & $\mathbf{5 6 . 5 9 2 2 6 3}$ & $\mathbf{0 . 0 1 6 3 9}$ & & \\
\hline
\end{tabular}

* denotes the rejection of the null hypothesis at $5 \%$ critical value

The results of the co-integration test are presented in table 4.3. The Eigen value and the trace statistics reveal at least two co-integrating relationships among the variables under study at a 5\% significant level. This therefore indicates the presence of long run or equilibrium relationship among variables. As such we estimate the error correction model.

\subsection{Vector Error Correction Model}

The VECM permits modeling adjustments that lead to a long run equilibrium relationship among the variables employed in this study.

Table 4.4 Vector Error Correction Model results

Co-integrating equations

\begin{tabular}{|llll|}
\hline Equation & Parms & chi2 & P>chi2 \\
\hline ce1 & 8 & 43068.47 & $\mathbf{0 . 0 0 0 0}$ \\
\hline
\end{tabular}

Identification: beta is exactly identified

Johansen normalization restriction imposed

\begin{tabular}{|c|c|c|c|c|c|c|}
\hline BETA & COEF. & STD. ERR. & $\mathbf{Z}$ & $\mathbf{P}>|\mathbf{Z}|$ & \multicolumn{2}{|c|}{ [95\% CONF. INTERVAL] } \\
\hline DLNFDI & 1 & $\theta$ & 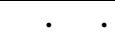 & 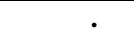 & & \\
\hline DLNDCP & -2.111219 & .0363883 & -58.02 & 0.000 & -2.182539 & -2.039899 \\
\hline DLNMCAP & 1.372509 & .0238239 & 57.61 & 0.000 & 1.325815 & 1.419203 \\
\hline DLNHC & -10.58237 & .0977598 & -108.25 & 0.000 & -10.77398 & -10.39077 \\
\hline DLNGDPPC & 5.320625 & .1305928 & 40.74 & 0.000 & 5.064668 & 5.576583 \\
\hline DLNTRADE & -8.987469 & .0580746 & -154.76 & 0.000 & -9.101293 & -8.873645 \\
\hline DLNCPI & -5.73246 & 1.873725 & -3.06 & 0.002 & -9.404893 & -2.060028 \\
\hline DLNENERGY & Y $-\mathbf{1 . 5 1 6 2 1 1}$ & .10486 & -14.46 & 0.000 & -1.721733 & -1.310689 \\
\hline DPOLSTAB & 11.30148 & 1.382143 & 8.18 & 0.000 & 8.592531 & 14.01043 \\
\hline DLNLAB & 4.803338 & .1290064 & -37.23 & 0.000 & -5.056186 & -4.55049 \\
\hline DLNINFL & .3980955 & .0350554 & 11.36 & 0.000 & .3293882 & .4668029 \\
\hline CONS & .3629087 & - & - & . & & \\
\hline
\end{tabular}

In Table 4.4, all the coefficients were significant at $1 \%$ level of significance. According to Solnik, (2000) when the variables are in logarithms and one cointegrating vector is estimated, the coefficients can be interpreted as long run elasticity. The long run relationship between foreign direct investment and its determinants for one cointegrating vector for Nigeria for the period 1980-2011 is displayed below (standard errors are displayed in parenthesis).

LNFDI=5.320625LNGDP - 5.73246 LNCPI -1.516211LNINFRAS+4.80338LNLAB+0.398095LNINFL+11.30148DPOLSTAB-
(0.1305928)
(1.873725)
(0.104686)
(4.80338)
(.0359554)
(1.382143)

8.987469LNTRADE+ 1.372LNMCAP- 2.111219LNDCP -10.58237LNHC

$\begin{array}{llll}(0.0580746) & (0.0238239) & (0.0363883) & (0.0977598)\end{array}$

..(9)

Foreign direct investment in Nigeria for the period under the study is determined by the growth of the economy, low level of corruption and supply of labour in different magnitude and this is in tandem with the works of Akinlabi et al(2011), More so, political stability and market capitalization have a positive and significant impact in attracting FDI inflows to Nigeria(Bisson,2011; Abdul,2011). On the other hand, Human capital and trade openness have negative and significant impact in determining FDI in Nigeria .As such, a $1 \%$ increase in the level of trade openness would hinder foreign direct investment. The negative relationship between FDI and trade openness could stem from the high level of importation in Nigeria as the country is an import dependent economy. This finding is in consonance with the works of Uwubanmwen \& Ajao (2012). 
Similarly an increase in the level of human capital would lead to a fall in FDI inflows to Nigeria. This may stem from the "brain drain" experienced in the country for the period under review.

\subsection{Granger Causality test}

\begin{tabular}{llll}
\hline Null hypothesis & \multicolumn{1}{c}{$\chi^{2}$} & Probability & decision \\
\hline Corruption does not granger cause FDI & 18.665 & $0.000^{* * *}$ & reject \\
FDI does not granger cause corruption & 0.20087 & 0.904 & Do not reject \\
Polstab. does not granger cause FDI & 2.5391 & 0.281 & do not reject \\
FDI does not granger cause polstab & 0.41972 & 0.811 & Do not reject \\
Human capital does not granger cause FDI & 7.2494 & $0.027 * *$ & Reject \\
FDI does not granger cause Human capital & 1.6343 & 0.442 & Do Not Reject \\
Trade does not granger cause FDI & 0.20206 & 0.904 & Do Not Reject \\
FDI does not granger cause TRADE & 9.0173 & $0.011^{* * *}$ & Reject \\
FDI does not granger cause GDPPC & 0.38109 & 0.827 & Do not reject \\
GDPPC does not granger cause FDI & 0.16217 & 0.444 & Do not reject \\
Energy supply does not granger cause FDI & 2.2169 & 0.330 & Do not reject \\
FDI does not granger cause Energy supply & 2.3298 & 0.312 & Do not reject \\
DCP does not granger cause FDI & 9.519 & $.009 * * *$ & Reject \\
FDI does not granger cause DCP & 0.79043 & 0.674 & Do Not Reject \\
Stock market does not granger cause FDI & 5.9959 & $0.050^{* *}$ & Reject \\
FDI does not granger cause stock market & 7.0576 & $0.029 * * *$ & Reject \\
FDI granger cause lab & 2.1367 & 0.344 & Do not reject \\
Lab does not granger cause FDI & 8.8939 & $0.012^{* * *}$ & reject \\
FDI Does Not Granger Cause Inflation & 3.6522 & 0.161 & Do Not Reject \\
Inflation Granger Causes Fdi & 10.31 & $0.006 * * *$ & Reject \\
\hline
\end{tabular}

$*, * *, * * *$, denotes significance at $1 \%, 5 \%$ respectively

Recall that although Cointegration between two variables does not infer direction of causality between the variables Economic theory guarantees that there is always Granger Causality in at least one direction. The Estimation results for the granger causality between the variables employed in this study are presented in Table 4.5. Here, we adopt the study by Gul and Ekinic (2006) by employing the chi-square statistics and probability to measure causality between the variables. Chi-Square statistics and probability values constructed under the null hypothesis of non causality show that there is a causal relationship between those variables. Table4. 5 provide the results of pair wise analyses.

Significant probability values denote rejection of the null hypothesis. This study rejects the null hypothesis if the probability value is more than $5 \%$ otherwise do not reject the null hypothesis if the probability value is less than $1 \%$. The study reveals a unidirectional relationship flowing from corruption to FDI and a bi directional relationship between stock market capitalization and FDI. No causal relationship was found between political stability, GDPPC energy supply and FDI. However, the result shows that FDI granger causes trade while financial development, inflation and labour also causes FDI.

\section{Conclusion and Policy Implications}

The aim of this study was to examine the role institutional quality plays in determining foreign direct investment in Nigeria. The results show that the level of FDI inflows is significantly related to the quality of institutions. More specifically, the results show that macroeconomic stability in terms of a less volatile inflation rate, a more developed financial market efficient and less corrupt institutions and political stability would have a positive impact on the FDI inflows of the countries in this sample. An important policy implication of this result is that the government in Nigeria can play an important role in promoting FDI. Thus, if Nigeria is to enjoy the benefits accrued to FDI, institutional reforms would be appropriate Moreover, as the quality of governance has a significant and positive impact on the determination of the income level, hence, an improvement in institutional quality would boost the country's income level which in turn indirectly has a major positive effect on the level of FDI inflows of the country. Direct and aggressive campaigning for investment projects is needed. The specific promotional tools depend, among other things, on a country's stage of development, its physical geography and the sectors targeted. Tools to be considered include special economic zones, export processing zones, industrial zones and favorable incentive schemes. As corruption is a symptom of fundamental economic, political, and institutional scourges, addressing corruption effectively means tackling these underlying problems. The major emphasis must be put on prevention that is, on reforming economic policies, institutions, and incentives, otherwise efforts to improve enforcement of anti-corruption legislation using the police, ethics offices or special watchdog agencies within government will not bear fruit. While emphasizing first and foremost the domestic causes of corruption, bribery by foreign firms also plays a significant role especially in developing countries like Nigeria. International institutions should enforce anti-bribery legislation abroad and make curbing corruption a priority when providing assistance to their member countries. 


\section{References}

[1]. Adelopo, I. et al (2009). Impact of corporate governance on Foreign Direct Investment in Nigeria. Journal of social science research, Electronic copy available at:http://ssrn.com/abstract=1514982

[2]. Adeoye, A.(2009) Macro-economic level corporate governance and FDI in emerging markets: Is there a close relationship? Journal of Economics and International Finance, Vol. 1(2), pp. 030-043, July, Available online at http://www.academicjournals.org/JEIF

[3]. Akinlo, A.(2004), Foreign Direct Investment and Growth in Nigeria: An Empirical Investigation Journal of Policy Modeling 26: 627-39.

[4]. Ajayi, I.S. (2006), Foreign Direct Investment in Sub-Saharan Africa: Origins, Targets, Impact and Potentials. African Economic Research Consortium, Kenya

[5]. Anghel, B. (2005). "Do Institutions Affect Foreign Direct Investment? International Doctorate in Economic Analysis, 2-40. ASEAN Bulletin (2010), ASEAN Secretariat

[6]. Anyanwu, J. C., (2007). Promoting of Investment in Africa. African Development, Review 18, No.1, April, $42-71$.

[7]. Anyanwu, J.C. (2012), Why Does Foreign Direct Investment Go Where It Goes?: New

[8]. Evidence from African Countries, Annals of Economics and Finance, Vol. 13(2), 425 -462

[9]. Artige, L., Nicolini, R. (2005), "Evidence on the Determinants of Foreign Direct Investment: The Case of Three European Regions." http://pareto.uab.es/wp/2005/65505.pdf

[10]. Asiedu, E. (2002), On the Determinants of Foreign Direct Investment to Developing Countries: Is Africa Different? World Development 30(1) pp. 107-119

[11]. Bénassy-Quéré, A., Coupet,M. \& Mayer,T.(2007) Institutional Determinants of Foreign Direct Investment. The World Economy

[12]. Bevan, A.A. and Estrin, S. (2000), the Determinants of Foreign Direct Investments in Transitional Economies, William Davidson Institute Working Paper 342

[13]. Bigliser ,G. and Garland,M.(2009) Electoral Systems and Incentives to Foreign Direct Investment: A Cross-National Study, Paper presented at the annual meeting of the ISA'S 50 ${ }^{\text {th }}$ Annual Convention Exploring the past, Anticipating the future, New York.

[14]. Bissoon,O.,(2011) Can Better Institutions Attract More Foreign Direct Investment (Fdi)? Evidence from Developing Countries International Conference On Applied Economics -ICOAE 59

[15]. Borensztein, E. R., De Gregorio,J. \& Lee, J. (1998). How Does Foreign Direct Investment Affect Economic Growth? Journal of International Economics 45 (1): 115-135

[16]. Busse, M. and Hefeker, C. (2007), - Political risk, institutions and foreign direct investment, European Journal of Political Economy, Vol. 23 (2), 397-415

[17]. Charkrabarti, A. (2001), the Determinants of Foreign Direct Investment: Sensitivity Analyses of Cross-Country Regressions. Kyklos, 54(1), pp. 89-114.

[18]. Daude, C. and Stein, E. (2007), Longitude Matters: Time Zones and the Location of Foreign Direct Investment, 71, Journal of International Economics, 96-112.

[19]. Dupasquier, C. \&Osakwe, P.N.(2005), Foreign Direct Investment in Africa: Performance, Challenges and Responsibilities Economic Commission for Africa, African Trade Policy Centre Working Paper no.21 Conference for Africa: AERC

[20]. Dunning, J. (1988) Explaining International Production: Unwin Hyman

[21]. Dunning J. (1993), Multinational Enterprises and the Global Economy, Reading, Mass:Addison-Wesley.

[22]. Dunning, J. (2001), the Eclectic (OLI) Paradigm of International Production: Past, Present and Future, International Journal of Economics and Business, 8(2) pp. 173-90.

[23]. Jensen, N.M. (2008), Political regimes and political risk: Democratic institutions and expropriation risk for multinational investors, Journal of Politics.

[24]. Jordaan, J. C. (2004), Foreign Direct Investment and Neighboring Influences. Unpublished doctoral thesis, University of Pretoria

[25]. Kaufmann, D, A, K \& Mastruzzi, M.(2006), Governance matters IV: Governance indicators for 1996-2005 World Bank', Washington, D.C.

[26]. Kim, H.(2010). Does Corporate Governance or Transparency affect Foreign Direct Investment? International Journal of Human and Social Sciences, Vol. 5(13)

[27]. Globerman, S., Shapiro, D. \& Tang, Y. (2004). Foreign direct investment in emerging and transition European countries, Center for International Business, Western Washington University

[28]. Gul, E. and Ekinc, A. (2006). The causal relationship between nominal interest rates and inflation: The case of Turkey. Scientific Journal of Administrative Development, 4: 54-69.

[29]. Masayuki, H and F. Ivohasina (2005), The Determinants of Foreign Direct Investment into Japan, Kobe University Economic Review 51.

[30]. Nonnemberg, M.B. \& Mendonca, M.J.C. (2004). The Determinants of Foreign Direct Investment in Developing Countries, Instituto de Pesquisa Economica Aplicada (IPEA), Rio de Janeiro

[31]. Noorbakhsh. F, Paloni, A \& Youssef, A. (2001) Human Capital and FDI Inflows to Developing Countries: New Empirical Evidence. World Development Vol.29 (9), pp. 1593-1610.

[32]. Nunnenkamp, Peter (2001) Foreign Direct Investment in Developing Countries: What policymakers should not do and what economists don't know, Kieler Diskussions beiträge, No. 380, http://hdl.handle.net/10419/2616

[33]. Nwankwo, A. (2006) the Determinants of Foreign Direct Investment Inflows (FDI) in Nigeria

[34]. $6^{\text {th }}$ global conference on Business \&Economics

[35]. Obadan, M.I. (1982), “Direct Investment in Nigeria: An Empirical Analysis,” African Studies Review, vol. XXV, No.1.

[36]. Oke ,B. O, Ezike J.E. \& Ojogbo,S. O.(2012) Locational Determinants of Foreign Direct Inevstment in Nigeria. International Business Research 5(4), pp103-107

[37]. Peter, N.(2002) Determinants of FDI in Developing Countries: Has Globalization Changed the Rules of the Game? Kiel Working Paper No. 1122, Kiel Institute for World Economics Duesternbrooker Weg 120 ,24105 Kiel (Germany).

[38]. Roberts, R. (2006), Incentives Matter, Library of Economics and Liberty.

[39]. Rodrik, D. (1998). Trade Policy and Economic Performance in Sub-Saharan Africa. National Bureau of Economic Research Working Paper 6562

[40]. Rogman, A. (1981) Inside the Multinationals; The Economics of Internal markets, New York: Colombia University Press.

[41]. Shatz, H. and A.J. Venables. 2000. "The geography of international investment". Policy Research Working Paper No. 2338. The World Bank, Washington, D.C

[42]. Solnik, B., 2000. International Investment, Addison Wesley Longman, Inc, New York 
[43]. Uwubanmwen, A. E. \& Ajao, M.G.(2012) The Determinants and Impacts of Foreign Direct Investment In Nigeria. International Journal of Business Management; Vol.7 (24) pp.67-76

[44]. Vasyechko,O.(2012). A Review of FDI Theories: An Application for Transition Economies, International Research Journal of Finance and Economics, Issue 89 (2012)

[45]. http://www.internationalresearchjournaloffinanceandeconomics.com

[46]. Vernon, R. (1996) International Investment and International Trade in the product life cycle.Quaterly Journal of Economics,80 pp. 190-207

[47]. Wafure, G. O. \& Nurudeen, A.(2010) Determinants of Foreign Direct Investment in Nigeria: An Empirical Analysis Vol. 10 (1) pp.26-35. Global Journal of Human Social Science

[48]. Wei, S.J. (2000). How Taxing is Corruption on International Investors? The Review of Economics and Statistics, 82/1, pp. 1-11.

[49]. Wernick, D.A. ,Haar,J. and Singh,S.(2009), Do Governing Institutions affect Foreign Direct Investment? Interenational Journal of Economics and Business Research, Vol.(3), 317-322.

[50]. World Bank database, (2012) available at: http://www.worldbank.org

[51]. Zheng, Y. (2006), Credibility versus Flexibility Political Institutions and Foreign Direct Investment, Mimeo, Annual Meeting of the American Political Science Association, August 30-September 3, Philadelphia, PA. World Investment Report 2010: Investing in a Low-carbon Economy (WIR10), UNCTAD. 